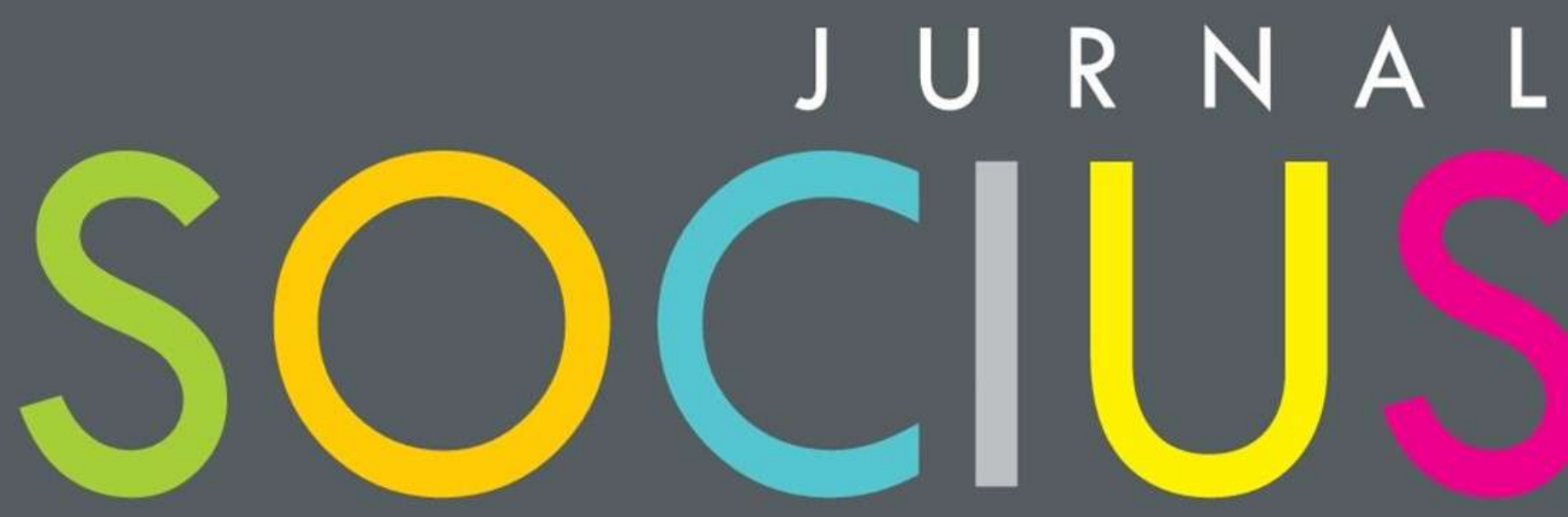

Journal of Sociology Research and Education

DITERBITKAN OLEH :

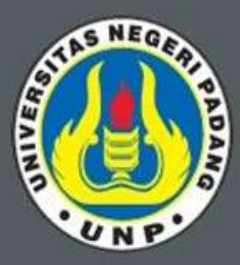

LABOR JURUSAN SOSIOLOGI FAKULTAS ILMU SOSIAL UNIVERSITAS NEGERI PADANG

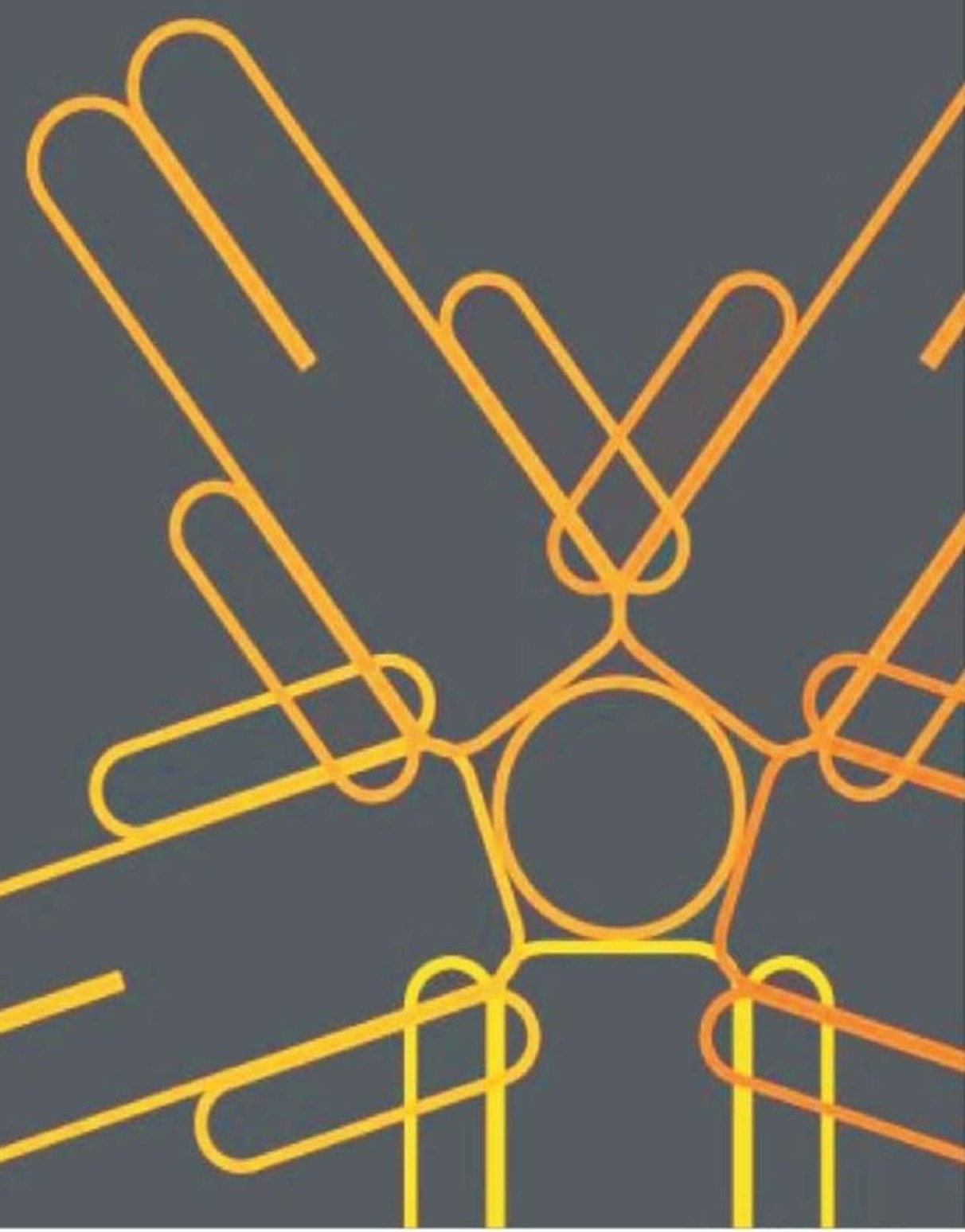




\section{SOCIUS}

Vol. 7, No. 1, Th. 2020

ISSN : 2356-4180 (cetak)

2442-8663 (online)

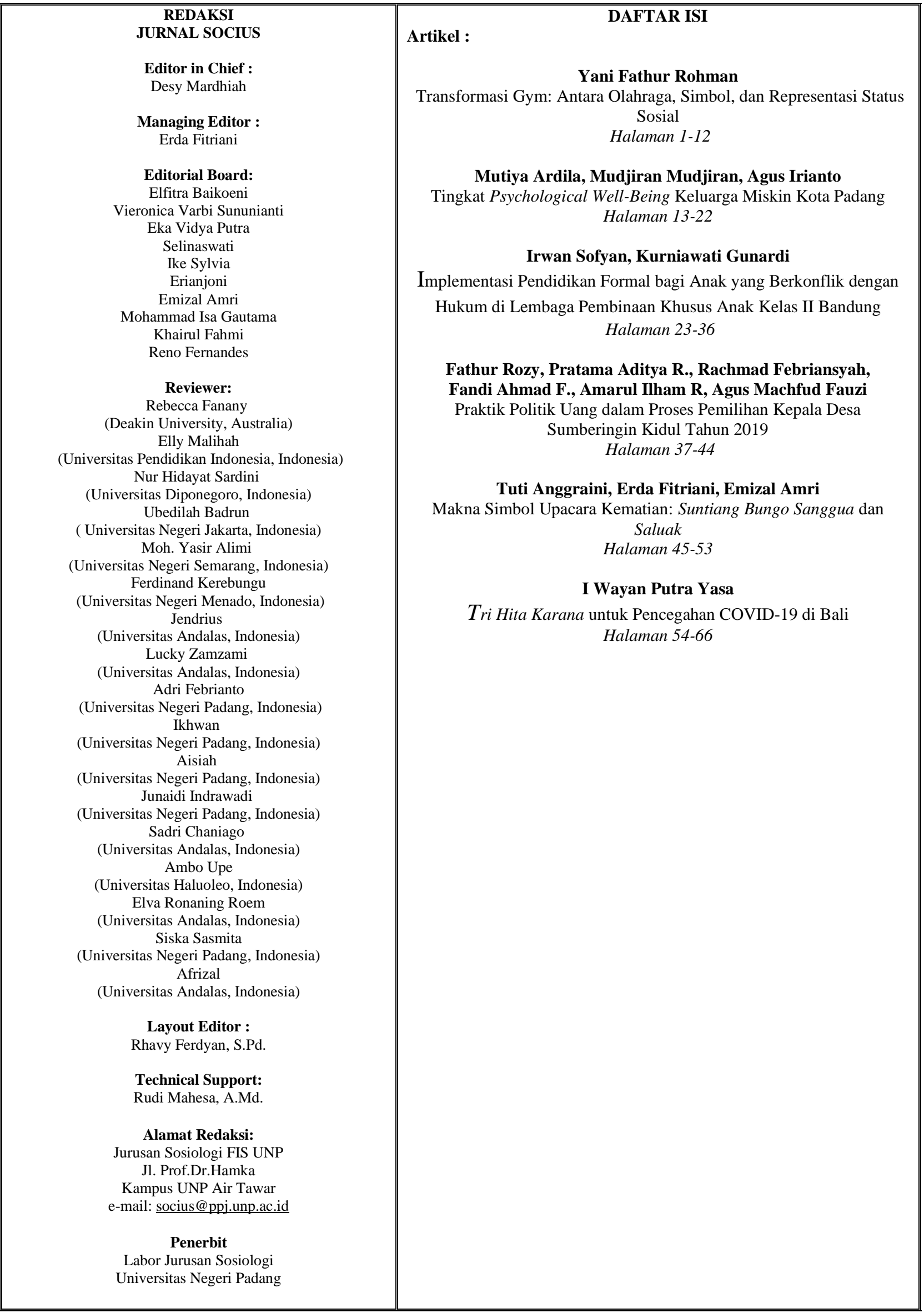




\title{
Tri Hita Karana untuk Pencegahan COVID-19 di Bali
}

\author{
I Wayan Putra Yasa \\ Universitas Pendidikan Ganesha \\ Email: yanputra666@gmail.com
}

\begin{abstract}
Abstrak
Kajian ini dilatar belakangi oleh adanya kebijakan pemerintah Provinsi Bali yang melibatkan Lembaga Desa adat di Bali sebagai tim penanganan COVID-19. Tujuannya adalah untuk mendapatkan pemahaman penanganan COVID-19 berlandaskan Tri Hita Karana oleh desa adat di Bali. Untuk mengkaji permasalahan penelitian maka dilakukan studi literatur. Hasil penelitian menunjukkan keterlibatan desa adat sebagai tim satgas penanganan COVID-19 diawali dengan pertemuan antara pemerintah Provinsi Bali dengan Majelis Desa Adat (MDA) Provinsi Bali dengan keluar surat keputusan nomor 472/ 1571/PPDA/DPMA dan Nomor 05/SK/MDA-ProvBali/III/2020 tertanggal 28 Maret 2020. Bentuk implementasi dari kebijakan itu dilaksanakan berdasarkan konsep Tri Hita Karana yang terdiri dari parhyangan dengan melakukan ritual agama seperti membatasi kegiatan adat dan pendekatan religius. Pawongan dengan melakukan pengawasan keluar masuknya masyarakat dan pembagian masker melalui pecalang (polisi adat), dan palemahan melakukan penyediaan tempat cuci tangan dan penyemprotan disinfektan di lingkungan desa adat.
\end{abstract}

Kata kunci: Bali, COVID-19, Desa adat

Abstract

This study is motivated by the policy of the provincial government of Bali which involves the Village Customary Institution in Bali as an agency handling COVID-19. The aim is to get an understanding of the COVID-19 handler based on Tri Hita Karana by traditional villages in Bali. To study the research problem, a literature study. The results of the study aimed at the involvement of traditional villages as the task force team for handling COVID-19, beginning with a meeting between the provincial government of Bali and the Bali Provincial Majelis Desa adat (MDA) with a decree number 472/1571 / PPDA / DPMA and Number 05 / SK / MDA-ProvBali / III / 2020 dated 28th March 2020. The form of implementation of the policy was carried out based on the Tri Hita Karana concept which consists of parhyangan by conducting religious rituals such as restricting traditional activities, religious approaches. Pawongan by monitoring the entry and exit of the community and the distribution of masks through pecalang (traditional police), and Palemahan provide a place to wash hands and to spray disinfectant in the customary village environment.

Keywords: Bali, COVID-19, Traditional village

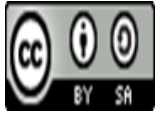

Received: May 13, $2020 \quad$ Revised: June 29, $2020 \quad$ Available Online: June 30, 2020

Jurnal Socius: Journal of Sociology Research and Education Vol. 7, No.1, Th. 2020

ISSN: Online 2442-8663 - Print 2356-4180 


\section{Pendahuluan}

Dunia saat ini sedang mengalami cobaan dari alam semesta berupa pandemi COVID19. Istilah COVID-19 adalah singkatan dari Coronavirus desease 2019, yakni penyakit yang disebabkan oleh infeksi virus Severe Acute Respiratory Syndrome Coronavirus 2 (SARSCoV-2) yang pertama kali muncul di kota Wuhan, Provinsi Hubei, Tiongkok pada bulan Desember 2019 (wikipedia, 2020). Akibat dari penyebaran virus COVID-19 yang semakin masif ke seluruh dunia. Akhirnya WHO sebagai lembaga kesehatan dunia tertinggi menaikkan status penyebaran COVID-19 sebagai pandemi tanggal 11 Maret 2020. Peningkatan status sebagai Pandemi karena peningkatan jumlah kasus serta menyebar luas ke seluruh dunia. Luasnya persebaran virus ini bisa dilihat dari perkembangan virus yang begitu cepat. Sejak kasus pertama bulan Desember 2019 sampai dengan bulan Mei 2020 virus COVID-19 telah menjangkiti 210 negara di dunia. Penyebaran kasus COVID-19 itu juga menjangkiti Indonesia pertanggal 2 Maret 2020, presiden RI bersama Menteri Kesehatan Dr. Terawan menyampaikan berita kasus 01 dan 02 (Ihsanuddin, 2020).

Pasca informasi kasus 01 dan 02 peningkatan jumlah pasien COVID-19 per hari semakin meningkat, data terakhir 9 Mei 2020. Rincian pasien COVID-19 di Indonesia berjumlah 13.645 orang, sembuh 2.607 orang, meninggal 959 orang. Kasus ini telah menyebar di seluruh Provinsi di Indonesia dengan jumlah pasien terbanyak ada di Provinsi DKI (covid.go.id, 2020). Dari grafik yang disampaikan pemerintah bahwa tingkat kesembuhan di Indonesia adalah 19,1\% dan tingkat kematian ada di $7 \%$ per 10 Mei 2020. Pemerintah telah melaksanakan berbagai kebijakan untuk menanggulangi persebaran COVID-19 agar virus ini segera bisa ditangani dan masyarakat Indonesia khususnya serta dunia bisa hidup normal kembali.

Upaya penanganan yang sistematis sudah diupayakan oleh pemerintah dengan membentuk gugus tugas penanganan COVID-19 berdasarkan Keputusan Presiden Republik Indonesia nomor 7 tahun 2020. Gugus tugas ini diketuai oleh Letnan Jenderal Doni Monardo Kepala Badan Nasional Penanggulangan Bencana. Penunjukan beliau sebagai ketua gugus tugas karena COVID-19 dipandang sebagai bencana non alam. Hal ini sesuai dengan UU No. $24 / 2007$ tentang Penanggulangan Bencana yang membagi bencana menjadi tiga jenis yaitu bencana alam, non alam dan sosial. Khusus untuk bencana non alam terdiri dari gagal teknologi, gagal modernisasi, epidemi, dan wabah penyakit (Pemerintah Republik Indonesia, 2007). Setelah pembentukan gugus tugas, maka gugus tugas bersinergi dengan kementrian, pemerintah daerah, TNI, dan Polri melakukan berbagai kebijakan.

Beberapa kebijakan penting yang diambil pemerintah sejak kasus pertama COVID-19 menjangkiti masyarakat Indonesia tertuang dalam Perpu Nomor 1 Tahun 2020 tentang Menghadapi Ancaman yang Membahayakan Perekonomian Nasional dan/atau Stabilitas Sistem Keuangan, Keppres Nomor 11 Tahun 2020 tentang Penetapan Kedaruratan Kesehatan Masyarakat Corona Virus Disease 2019 (Covid-19), dan PP Nomor 21 Tahun 2020 tentang Pembatasan Sosial Berskala Besar Dalam Rangka Percepatan Penanganan Corona Virus Disease 2019 (Covid-19) (Kemenkes RI, 2020; Siregar \& Zahra, 2020). Dari ketiga aturan yang dikeluarkan setidaknya ada 10 komponen penting yang menjadi fokus penanganan COVID-19 terutama dampaknya dalam berbagai bidang. Bidang-bidang yang dimaksud antara lain jaringan pengamanan berupa peningkatan jumlah besaran penerima bantuan keluarga harapan, kenaikan penerima kartu sembako, kenaikan anggaran kartu prakerja, subsidi listrik 450 VA dan 900 VA, cadangan kebutuhan pokok, relaksasi angsuran 
perbankan, penyesuaian anggaran belanja pemerintah, penyesuaian defisit belanja negara, serta kebijakan PSBB (Pengendalian Sosial Berskala Besar) (AMN, 2020).

Berpedoman pada berbagai aturan yang sudah diterapkan di atas, pemerintah daerah mengimplementasikannya sesuai dengan situasi dan kondisi yang ada di daerahnya. Hal yang sama juga berlaku di Bali, sebagai salah satu provinsi yang rawan dalam penyebaran COVID19. Penyebab kerawanan ini karena masyarakat Bali memiliki tingkat mobilitas tinggi akibat dari tujuan wisata dunia. Selain itu, Bali menjadi salah satu pusat urbanisasi dari berbagai daerah di Indonesia. Oleh karena itu, penting segera mengimplementasikan kebijakan pemerintah pusat. Bentuk implementasi di Provinsi Bali dengan membentuk satgas gotong royong yang melibatkan komponen desa adat yang awalnya diberi nama desa pakraman (balitribune.co.id, 2020). Desa Pakramanyang sejak tahun 2019 diubah menjadi desa adat adalah pemerintahan lokal Bali yang mengurusi masalah adat dan budaya Bali (Sunu, 2015).

Kebijakan ini tertuang dengan adanya pertemuan antara Pemerintah Provinsi Bali dan Majelis desa adat Bali pada 29 Maret 2020. Pertemuan yang dilaksanakan di Kantor Gubernur Bali memutuskan dibentuknya satgas gotong royong antara desa adat dan Desa Dinas. Berdasar surat keputusan bersama nomor 472/ 1571/PPDA/DPMA dan Nomor 05/SK/MDA-ProvBali/III/2020 tertanggal 28 Maret 2020 yang ditandatangani oleh Gubernur Bali dan Ketua Majelis Agung MDA Provinsi Bali. Penanganan kasus berbasis desa adat ini dilakukan karena sudah ada kasus COVID-19 di Bali yaitu 9 orang dengan korban meninggal dua orang Warga Negara Asing (Redaksi WE Online, 2020).

Adanya keputusan bersama ini menjadi dasar komponen masyarakat adat yang ada di Bali untuk bersama-sama mencegah penyebaran COVID-19 di Provinsi Bali. Hal ini penting karena di Bali seperti diketahui terdapat dualisme pemerintahan yaitu pemerintahan dinas yang berorintasi dengan aturan pemerintah secara nasional. Di sisi lain ada pemerintahan desa adat yang berdasarkan kearifan lokal budaya Bali. Masifnya penyebaran COVID-19 tentu juga perlu kebijakan lain, pendekatan sosial budaya penting juga dilakukan agar lebih cepat dapat mengendalikan COVID-19 (Febriyandi, 2020). Untuk mendukung pemerintah dalam menyukseskan pencegahan COVID-19, maka lembaga desa adat Bali mengimplementasikan kebijakan itu melalui falsafah tri hita karana. Tri Hita Karana itu memiliki pengertian tiga penyebab kesejahteraan atau kebahagiaan yang terdiri dari parhyangan (hubungan manusia dengan Tuhan), pawongan (hubungan manusia dan manusia), palemahan ( hubungan manusia dan alam semesta) (Karmini et al., 2019). Situasi ini tentunya berbeda dengan penanganan COVID-19 yang dilakukan oleh masyarakat lain di Indonesia. DKI Jakarta, Jawa Barat, Jawa Timur, menerapkan PSBB sebagai upaya untuk mencegah penyebaran COVID-19 (Hadiwardoyo, 2020).

Kajian tentang penangangan dan kebijakan tentang dampak dari COVID-19 sudah dilakukan, misalnya tentang dampak dari pelaksanaan lockdown dalam rangka mencegah penyebaran COVID-19 (Lestari, 2020). Penelitian ini berfokus pada dampak baik dan buruk dari pelaksanaan lockdown, terutama jika dilaksanakan di Indonesia khususnya Jakarta sebagai ibu kota negara. Kajian lainnya tentang COVID-19 berhubungan dengan fenomena panic buying yang terjadi ketika COVID-19 (Harahap, 2020). Secara spesifik penelitian ini melihat fenomena pembelian barang yang tidak terkontrol (panic buying) karena ketakutan akan dampak virus COVID-19. Selanjutnya kajian tentang dampak COVID-19 kepada ekonomi nasional (Hadiwardoyo, 2020) yang menjelaskan dampak ekonomi sebelum pelaksanaan PSPB di Jabodetabek. Selain itu ada juga kajian tentang Desa Pakraman yang merupakan nama awal dari desa adat telah dikaji dengan judul "Memperkuat Ketahanan Sosial Budaya Melalui Konsep Ajaran "Tri Hita Karana” (Suarmini, 2011). Hasil kajian ini 
menjelaskan bagaimana konsep Tri Hita Karana mampu menjadi salah satu benteng untuk mempertahankan sosial budaya masyarakat Bali. Berpedoman dari kajian tersebut, belum ada yang secara spesifik mengkaji tentang penanganan COVID-19 berbasis desa adat di Bali dengan menerapkan falsafah Tri Hita Karana. Oleh karena itu penting untuk dilakukan kajian ini, sehingga bisa memberikan pemahaman dan model penanganan covid berbasis desa adat dengan berpedoman pada falsafah Tri Hita Karana di Bali. Diharapkan selanjutnya hasil penelitian ini bisa memberikan gambaran konsep falsafah Tri Hita Karana, implementasi ajaran Tri Hita Karana dalam penanganan COVID-19 di Bali, serta berbagai permasalahan yang dihadapi dalam mengimplementasikan Tri Hita Karana dalam mencegah COVID-19 di Bali.

\section{Metode Penelitian}

Artikel ini ditulis berdasarkan hasil penelitian studi literatur yang menganalisis falsafah Tri Hita Karana dalam menangani penyebaran COVID-19 berbasis desa adat di Bali. Sumber data berasal dari artikel ilmiah kajian tentang COVID-19, desa adat, peraturan kebijakan tentang COVID-19 yaitu Undang-Undang Nomor 24 Tahun 2007, PP Nomor 21 Tahun 2020, Keppres Nomor 11 Tahun 2020, Perpu Nomor 1 Tahun 2020 surat keputusan bersama Nomor 472/ 1571/PPDA/DPMA dan Nomor 05/SK/MDA-ProvBali/III/2020, dan awig-awig desa adat Sogra, desa adat Runuh dan desa adat Padang bulia. Selain itu kajian sumber data juga dilakukan pada berita di media massa online. Beberapa artikel yang ditulis di media online antara lain Warta Ekonomi (Wartaekonomi.co.id), Bali Post (www.balipost.com), Idn Time Bali (bali.idntimes.com), Tribun Bali (Bali Tribunnews.com), Bali Puspa News (balipuspanews.com), Kompas (Kompas.com), dan gatracom (gatra.com) yang memuat berita dari tanggal Maret sampai Juni 2020). Data yang sudah terkumpul kemudian ditriangulasi sumber yang berasal dari sumber artikel ilmiah, berita di media massa, peraturan perundangundangan dan awig-awig / peraturan yang berlaku di masing-masing desa adat seperti disebutkan di atas. Keseluruhan disajikan secara deskriptif kritis selayaknya penelitian studi literatur atau kepustakaan (Danandjaja, 2014).

\section{Hasil danPembahasan}

\section{Tri Hita Karana sebagai Pedoman Desa Adat di Bali}

Tri Hita Karana adalah pedoman hidup yang dipakai oleh masyarakat Bali khususnya yang beragama Hindu. Istilah Tri Hita Karana pertama kali muncul pada tanggal 11 Nopember 1966, pada waktu diselenggarakan Konferensi Daerah I Badan Perjuangan Umat Hindu Bali bertempat di Perguruan Dwijendra Denpasar. Konferensi tersebut diadakan berlandaskan kesadaran umat Hindu akan dharmanya untuk berperanserta dalam pembangunan bangsa menuju masyarakat sejahtera, adil dan Makmur berdasarkan Pancasila (Sukarma, 2016). Kemudian istilah Tri Hita Karana ini berkembang, meluas, dan memasyarakat. Secara leksikal Tri Hita Karana berarti tiga penyebab kesejahteraan (Tri = tiga, Hita $=$ sejahtera, Karana $=$ penyebab). Secara lebih luas Tri Hita Karana mengandung pengertian tiga penyebab kesejahteraan itu bersumber pada keharmonisan. Keharmonisan yang dimaksud berkaitan dengan tiga hubungan yaitu hubungan manusia dengan Tuhan, sesama manusia, dan dengan alam. Dalam Tri Hita Karana itu dituangkan disebut dengan konsep 1) parhyangan (Hubungan Manusia dengan Tuhannya), 2) pawongan (Hubungan Manusia dengan sesamanya) dan 3) palemahan (Hubungan Manusia dengan alam 
lingkungannya) (Adharinalti, 2012). Falsafah Tri Hita Karana ini kemudian menjadi pedoman dan menjiwai seluruh kebijakan dan tata laksana desa adat di Bali.

Penjelasan tentang hubungan Tri Hita Karana dan desa adat di Bali tersirat dalam konsep desa adat. Desa adat menurut Perda Provinsi Bali nomor 4 tahun 2019 Pasal 1 ayat 8 disebutkan bahwa desa adat merupakan kesatuan masyarakat hukum adat di Bali yang memiliki wilayah, kedudukan, susunan asli, hak-hak tradisional, harta kekayaan sendiri, tradisi, tata krama pergaulan hidup masyarakat secara turun temurun dalam ikatan tempat suci (kahyangan tiga atau kahyangandesa), tugas dan kewenangan serta hak mengatur dan mengurus rumah tangganya sendiri. Lebih lanjut desa adat memiliki beberapa syarat mutlak yaitu 1) memiliki batas-batas tentu yang jelas. Umumnya berupa batas alam seperti sungai, hutan, jurang, bukit atau pantai; 2) mempunyai anggota (krama yang jelas), dengan syarat tertentu; 3) mempunyai kahyangan tiga atau kahyangan desa, atau pura lain yang mempunyai fungsi dan peranan sama dengan kahyangan tiga; 4) mempunyai otonomi, baik ke luar maupun ke dalam; dan 5) mempunyai suatu pemerintahan adat, dengan kepengurusan (prajuru adat) sendiri (Pitana, 1994: 113). Berpedoman pada syarat adat tersebut dan konsep Tri Hita Karana maka keduanya merupakan satu kesatuan utuh (Sudiatmaka \& Apsari Hadi, 2018). Tri Hita Karana sebagai jiwanya dan desa adat bisa dipandang sebagai raganya. Sehingga tidak salah banyak pakar menyampaikan bahwa taksu Bali ada di Tri Hita Karana yang menjiwai desa adat (Setiada, 2003).

Bentuk implementasi dari Tri Hita Karana dalam fisik desa adat bisa dilihat dalam setiap ruang kehidupan budaya Bali yang ada. Bentuk perwujudan dari Tri Hita Karana dalam desa adat di Bali dalam aspek parhyangan bisa dilihat dari keberadaan tempat suci berupa pura. Pura di Bali ada berbagai jenis untuk lingkungan desa adat yakni Pura Kahyangan Desa yang terdiri dari Pura Puseh, Pura Bale Agung, dan Pura Dalem. Di samping itu dilingkungan ikatan klien keluarga umumnya ada Pura Dadya. Di keluarga terkecil yakni di rumah ada sanggah kemulan yang menjadi pusat ritual religius sebagai umat Hindu (Arjawa \& Jayantiari, 2017). Implementasi pawongan dalam masyarakat adat Bali bisa dilihat dari keberadaan anggota masyarakat adat yang disebut krama adat, hubungan atau relasi sosial yang ada di masyarakat Bali seperti keluarga, kelompok sosial atas dasar profesi dikenal dengan sekaa. Kemudian konsep palemahan ini terwujudkan dalam bentuk lingkungan desa adat yang diatur dalam aturan adat yang disebut awig-awig (Sudantra, 2014). Wilayah desa adat ada yang disebut tanah ayahan desa /karang desa yaitu tanah yang memiliki kewajiban untuk membayar pajak kepada pihak desa setiap tahun. Bentuk pajak itu bisa berupa kewajiban untuk bekerja bagi pengelolanya atau kewajiban membayar dalam bentuk uang ataupun benda. Kemudian tanah pribadi yang dimiliki oleh pribadi di wilayah adat yang kewajibannya kepada negara berupa pajak (Setiada, 2003).

Ketiga komponen Tri Hita Karana ini menjadi pedoman dalam segala pelaksanaan ritual adat-istiadat yang dilaksanakan oleh desa adat di Bali. Bentuk-bentuk aktivitas adat istiadat yang terjadi adalah cerminan dari hubungan harmonis manusia Bali. Hubungan manusia dengan Tuhannya, kemudian dengan manusia yang lainnya dan juga dengan alam semesta yang menjadi tempat tinggal manusia itu. Datangnya wabah pandemi COVID-19 di seluruh dunia termasuk di Bali direspon dengan tiga tatanan tersebut. Karena masyarakat Bali sangat percaya bahwa segala hal yang terjadi dalam kehidupan manusia dipengaruhi oleh tiga dimensi itu. Oleh karena itu, untuk menghadapinya pun harus melalui ketiga jalan tersebut. Artinya manusia harus harmonis dengan Tuhan melalui ritual agama dan adat Bali, harmonis dengan manusia dengan melakukan restrukturisasi kehidupan sosial masyarakat Bali, dan 
memperbaiki hubungan manusia dengan alam melalui pola hidup bersih dan sehat sesuai protokol pencegahan COVID-19.

\section{Implementasi Tri Hita Karana dalam Pencegahan COVID-19 di Bali}

Upaya untuk melakukan pencegahan penyebaran COVID-19 di Provinsi Bali memakai pendekatan yang berbeda yaitu dengan melibatkan komponen desa adat (Agung, 2020). Hal ini penting dilakukan karena di Bali secara sistem pelaksanaan pemerintahan terdapat dua organisasi yang saling berperan penting. Pertama, itu adalah desa dinas yang berkaitan dengan administrasi kenegaraan seperti KTP, akta pernikahan, akte kelahiran, dan sebagainya. Kedua adanya desa adat yang mengatur masyarakat Bali dalam konteks sosial budaya sebagai orang Bali khususnya beragama Hindu. Hal-hal yang berkaitan dengan desa adat bisa dilihat dari ritual adat dan agama, kehidupan sosial seperti perkawinan yang melibatkan adat, kematian yang harus melibatkan adat, dan hal lainnya. Desa dinas secara aturan berpedoman pada perundang-undangan yang berlaku di negara Indonesia. Sedangkan desa adat berlandaskan pada awig-awig atau peraturan desa adat yang bersifat lokalitas perdesa adat yang tertulis maupun tidak tertulis (Sumarjo, 2018). Begitu pula berkaitan dengan kewenangan dan kewajibannya diikat oleh aturan tersebut yang dibatasi oleh awigawig (K. N. Setiada, 2003).

Berkenaan dengan adanya pandemi COVID-19 ini, maka pemerintah dinas melalui Gubernur Bali berkoordinasi dengan ketua Majelis Desa adat Provinsi Bali. Melalui koordinasi dan sinergi ini akhirnya keluar surat keputusan bersama nomor 472/ 1571/PPDA/DPMA dan Nomor 05/SK/MDA-ProvBali/III/2020 tertanggal 28 Maret 2020 yang ditantangani oleh Gubernur Bali I Wayan Koster dan dari Majelis Desa adat yaitu Ida Panglingsir Agung Putra Sukahat. Melalui keputusan tersebut kemudian dibentuklah tim satuan tugas penanganan COVID-19 berbasis desa adat. Dalam waktu yang singkat di Bali terbentuk 700 satgas dan ditarget 1493 satgas COVID-19 sesuai dengan jumlah dari desa adat yang ada di Bali (Devita, 2020).

Sinergi antara pemerintah daerah dengan desa adat di Bali memang menjadi suatu yang umum dilakukan, hal ini tidak bisa dilepaskan dari adanya relasi sosial yang bersifat mutualisme di antara ke dua lembaga tersebut. Ini tidak bisa dilepaskan dari posisi lembaga desa adat yang sangat strategis dalam tata kelola kehidupan masyarakat Bali. Kajian Adharinalti menjelaskan terjadi sinergi yang sangat erat antara Desa adat dan Desa Dinas dalam menjaga kehidupan masyarakat Bali berjalan dengan baik. Satgas gotong royong berbasis Desa adat yang dibangun memiliki tugas untuk melakukan pencegahan secara sekala (nyata) dan niskala (tidak nyata/ spiritual) dengan melibatkan krama desaadat(warga desa adat) dan yowana (sebutan untuk pemuda di Bali) (Adharinalti, 2012). Sekaligus bekerjasama dengan satgas COVID-19 yang lainnya yang sudah dibentuk di Desa Dinas. Implementasi pencegahan dan penanggulan secara sekala dan niskala tersebut dipraktikan dalam konsep Tri Hita Karana sebagai falsafah desa adat bisa dilihat dalam uraian berikut.

\section{Parhyangan}

Penanganan COVID-19 berbasis desa adat di Bali memakai pendekatan sekala dan niskala. Aspek niskala berkaitan dengan aspek kepercayaan dan religiusitas masyarakat Bali. Sesuai dengan Surat Edaran nomor 472/ 1571/PPDA/DPMA dan Nomor 05/SK/MDAProvBali/III/2020 tertanggal 28 Maret 2020, maka seluruh desa adat di Bali diberikan tugas untuk menyampaikan kepada masyarakat luas. Bentuk informasinya berupa himbauan agar melakukan doa niskala, memohon berkah (nunas ica) bersama pemuka agama (pemangku) di Pura Kahyangan Tiga Desa Adat. Caranya dengan mempersembahkan upakara yaitu nyejer 
daksina (mempersembahkan daksina yaitu alat ritual dalam agama Hindu) sampai COVID-19 berakhir dan ada pemberitahuan lebih lanjut. Kemudian desa adat juga dihimbau untuk melakukan doa bersama dalam jumlah yang terbatas untuk memohon kepada Tuhan Yang Maha Esa (Ida Bhatara Sesuhunan) sesuai dengan adat kebiasaan di masing-masing desa (drestha desa adat) setempat agar wabah COVID-19 segera berakhir demi keharmonisan alam, krama, dan budaya Bali.

Selain itu, sebelum diterbitkan surat keputusan bersama untuk membentuk Satgas Gotong Royong berbasis desa adat. Pemerintah Provinsi Bali bersama Parisadha Hindu Dharma Indonesia (PHDI) dan Majelis Desa Adat Bali juga telah mengeluarkan Surat Edaran Bersama mengenai pembatasan perayaan Nyepi, dengan Nomor: 019/PHDI-Bali/III/2020, Nomor: 019/ MDA-Prov Bali/2020 dan Nomor 510/Kesra/ B-Pem-Kesra. Dalam surat edaran tertanggal 23 Maret 2020 seluruh rangkaian hari Raya Nyepi harus dilaksanakan dengan memperhatikan protokol kesehatan pencegahan COVID-19. Hal yang paling menimbulkan polemik yaitu tentang pengarakan ogoh-ogoh yang sudah disiapkan oleh masyarakat Bali. Tetapi berdasarkan isi surat edaran tersebut dihimbau untuk ditiadakan. Di masyarakat secara umum terjadi perpecahan ada pro dan kontra, namun itu dapat diatasi dengan pemberian pemahaman dari pihak desa adat. Ketika pengrupukan yaitu ritual menetralisir kekuatan negatif satu hari menjelang hari raya Nyepi. Pengrupukan menjelang hari raya Nyepi yang biasanya identik dengan keramaian tahun 2020 ini benar-benar berbeda. Tidak ada pawai ogoh-ogoh, semua masyarakat Bali mengutamakan pencegahan menyebaran COVID-19.

Kebijakan lainnya dalam konteks parhyangan yang bersifat sekala dikeluarkan oleh pemerintah bersinergi dengan Majelis Desa Adat dan Parisada Hindu Dharma Indonesia Provinsi Bali yakni membatasi berbagai aktivitas religius yang melibatkan banyak orang. Sesuai dengan protokol penanganan COVID-19 maksimal peserta kegiatan maksimal 25 orang (Suherni, 2020). Jumlah ini adalah jumlah maksimal untuk tempat pelaksanaan persembahyangan yang luas seperti melasti yang dilakukan di pantai. Pura yang memiliki luas lokasi yang memungkinkan peserta sembahyang bisa tetap menjaga jarak aman 1,5-2 meter setiap peserta persembahyangan, namun jika tidak bisa memenuhi hal tersebut dibatasi 2-3 orang saja. Pendekatan berbasis Tri Hita Karana ini penting dilakukan karena Bali sebagai kesatuan masyarakat memiliki tingkat kompleksitas yang sangat tinggi. Untuk memahami berbagai persoalan tersebut peranan desa adat sangat dibutuhkan, karena di masing-masing desa adat sendiri ada perbedaan yang kompleks sesuai dengan desa, kala, patra (tempat, waktu, situasi) yang ada di setiap desa adat. Di samping itu Bali dengan mayoritas Hindu lebih mudah digerakan jika memakai desa adat. Sebab keterikatan orang Bali bersama adat tidak hanya bersifat administratif formal seperti desa dinas, tetapi keterikatan sosial budaya religius yang bisa memberi dampak luas dalam kehidupannya.

\section{Pawongan}

Pada aspek pawongan kebijakan untuk pencegahan COVID-19 berbasis desa adat bisa dilihat dari aspek pelibatan pecalang (polisi adat Bali) yang turut serta dalam mengawasi kebijakan pemerintah. Pecalang ini ikut melakukan tugas dalam mengawasi pergerakan masyarakat yang tidak penting untuk mencegah meluasnya penyebaran COVID-19. Ini menjadi ciri khas dari setiap kegiatan dinas, sosial budaya, dan religius di Bali,sehingga pecalang memiliki posisi yang sangat vital. Pecalang dalam hal tertentu bisa lebih efektif dalam menyelesaikan permasalahan di masyarakat Bali.

Tugas pecalang selain mengawasi umumnya juga melakukan penyaluran berbagai bantuan yang berikan oleh pemerintah maupun pihak swasta atau perorangan kepada masyarakat di wilayahnya. Bantuan berupa CSR dari pihak perusahaan swasta sebagai 
implementasi dari ajaran Tri Hita Karana juga bisa dilakukan dengan bantuan desa adat (Rahmawati et al., 2019). Bantuan yang berupa logistik kebutuhan pokok, masker, tempat cuci tangan, hand sanitizer, maupun bantuan lainnya. Pecalang sebagai bagian dari lembaga adat menjadi aktor penting dalam mencegah penyalahgunaan bantuan yang tidak tepat atau salah sasaran. Pecalang di Bali memiliki fungsi kontrol sosial terutama yang berhubungan dengan pelaksanaan adat Bali (Arsawati, 2016). Sinergi ini dalam implementasinya cukup efektif dalam mendistribusian dan mengendalikan penyebaran COVID-19 di Bali. Satgas COVID-19 gotong royong berbasis desa adat ini juga membangun posko di setiap perbatasan desa untuk mengecek lalu lintas penduduk yang masuk dan keluar desa adat. Posko ini dijaga secara gotongroyong yang melibatkan pecalang, hansip, karang taruna dan sukarelawan lainnya. Kemudian dibantu oleh Babinsa dan Babinkantibmas, sehingga pelaksanaannya benar-benar sesuai aturan yang berlaku. Selanjutnya satgas gotong royong ini juga bertugas untuk menjaga Posko Karantina berbasis desa adat yang dibuat untuk PMI (Pekerja Migran Indonesia) yang baru pulang ke desanya. PMI ini dikarantina di sekolah-sekolah yang ada di sekitar desa adat. Karantina ini penting dalam rangka memutus rantai penyebaran COVID-19 lebih luas, sehingga mudah dikendalikan (Ibnu \& Setiawan, 2020). Untuk menyukseskan kegiatan karantina itu, segala kebutuhan konsumsi dipersiapkan oleh desa adat termasuk mengawasi, sehingga tidak ada yang tidak disiplin melakukan karantina. Di samping itu ada juga upaya penghentian aktivitas objek wisata, berupa penutupan sementara objek wisata yang dikelola oleh desa adat, pemerintah maupun swasta(Mustofa, 2020).

\section{Palemahan}

Palemahan merupakan hal-hal yang mengatur hubungan manusia dengan alam dan sekaligus menjaga supaya alam di sekitar kita tetap lestari (Sukarma, 2016). Begitu juga halnya dalam penanganan COVID-19 di Bali, maka unsur palemahan tidak bisa diabaikan. Adapun yang termasuk dari unsur palemahan adalah tempat beraktivitas manusia seperti rumah penduduk, balai desa, pasar (Budiantara, 2017). Implementasi kebijakan desa adat berbasis Tri Hita Karana di bidang palemahan yaitu berupa penyediaan disinfektan, penyempotan disinfektan secara berkala, penyediaan tempat cuci tangan di lokasi yang strategis, seperti di Pura Desa, Bale Banjar, depan gang, batas desa, dan pasar desa. Berikut ini gambar satgas gotongroyong yang sedang melaksanakan tugas untuk mencegah COVID19 di Desa Adat Sogra.

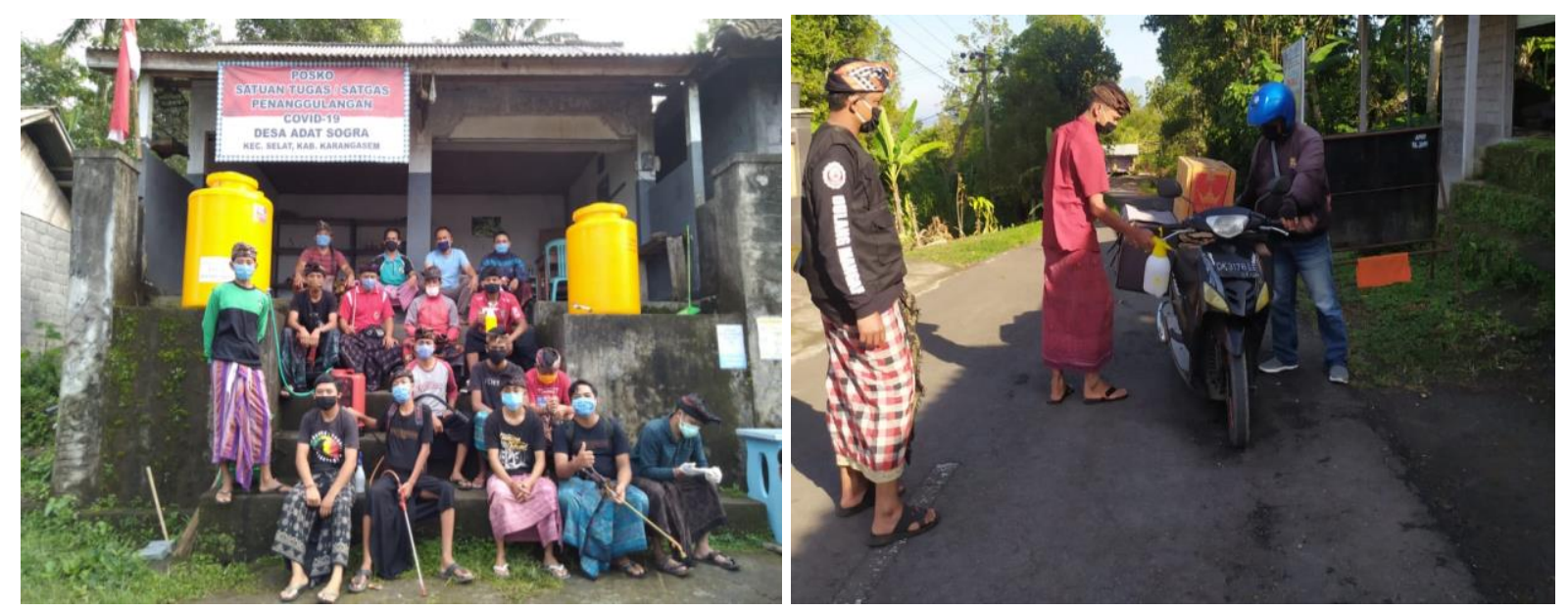

Gambar 1. Satgas Gotongroyong Desa adat Sogra, Karangasem, Bali 
Keseluruhan itu dilakukan oleh Satgas gotong royong berbasis desa adat di seluruh Bali. Penyemprotan dilakukan secara berkala, umumnya dilakukan oleh Satgas gotong royong setiap hari minggu. Proses penyemprotan disinfektan dilakukan secara menyeluruh di setiap sudut desa adat, dari fasilitas umum seperti balai banjar, tempat suci, sampai ke rumahrumah pribadi. Kegiatan tersebut terus digalakkan oleh satgas desa adat sebagai upaya untuk mencegah penyebaran virus COVID-19.

Kemudian untuk meningkatkan kebersihan dan kesadaran masyarakat dalam mencegah penyebaran COVID-19, Satgas desa adat juga memasang berbagai himbauan di lingkungan desa adat. Himbauan ini terdiri dari beberapa hal penting dalam usaha pencegahan penyebaran COVID-19 yang secara umum terdiri dari 1) budaya hidup bersih, 2) tidak menyentuh mata, hidung, mulut, 3) menjaga kesehatan tubuh, 4) menghindari kerumunan, 5) selalu memakai masker jika bepergian. Langkah-langkah sosialisasi untuk pencegahan tersebut cukup efektif dalam mencegah penyebaran COVID-19 (Tim COVID-19 IDAI, 2020). Langkah lainnya yang juga penting dilakukan desa adat adalah penyediaan alat cuci tangan di tempat-tempat umum yang biasa dipakai sebagai tempat aktivitas masyarakat, misalnya pasar, balai banjar, pura, pintu masuk desa adat, dan berbagai tempat lainnya yang dianggap penting. Banyaknya sarana cuci tangan yang ada di wilayah desa adat secara tidak langsung kemudian akan membuat masyarakat sadar pentingnya pencegahan COVID-19.

\section{Problematika Desa Adat dalam Implementasi Pencegahan COVID-19 berbasis Tri Hita Karana di Bali}

Penanganan pencegahan penyebaran COVID-19 berbasis adat di Bali bukan berarti tanpa permasalahan, harus diakui dalam tatanan implementasi banyak permasalahan yang muncul. Namun demikian pihak desa adat yang bersinergi dengan pemerintah daerah terus melakukan inovasi dan perbaikan. Beberapa masalah penting yang muncul dibeberapa desa adat berdasarkan hasil kajian yang dilakukan antara lain:

\section{Pemahaman standar kesehatan WHO yang berbeda}

Permasalahan awal yang muncul dalam penanganan covid berbasis adat adalah pelaksanaan di masyarakat belum memiliki pemahaman yang sama mengenai standar kesehatan yang harus dijalankan. Permasalahan ini tidak bisa dihindari karena kurang sosialisasi dan juga terbatasnya waktu antara surat keputusan dan pelaksanaan di lapangan. Situasi itu menyebabkan di beberapa desa adat standar yang dipakai dalam pencegahan COVID-19 berbasis adat terdapat perbedaan. Misalnya pemakaian masker, dalam hal ini banyak pihak pelaksana atau satgas tugas berbasis adat sendiri tidak disiplin memakai masker. Begitu juga dengan standar pembuatan disinfektan yang tidak terstandarisasi. Desinfektan yang dibuat tidak memakai standar komposisi yang telah ditetapkan oleh WHO maupun oleh dinas kesehatan (Putra, 2020). Masalah lain yang juga muncul berkaitan dengan penyemprotan disinfektan di pintu-pintu masuk wilayah desa adat yang tidak serempak bahkan ada desa yang tidak melakukan. Sedangkan di desa lain melakukan dengan sangat ketat, hal ini menyebabkan terjadinya perbedaaan standar pencegahan yang berlaku di setiap daerah. Upaya pencegahan itu harusnya jelas seperti yang dilakukan buat ASN yaitu dengan bekerja dari rumah (Work From Home) (Kemendikbud, 2020).

Persoalan itu muncul di awal pelaksanaan satgas COVID-19 berbasis adat, seiring dengan berjalannya waktu dapat diselesaikan oleh satgas COVID-19. Adanya sosialisasi dan informasi dari berbagai media baik melalui himbuan secara tertulis ataupun media elektronik serta media sosial. Pencegahan COVID-19 semakin baik dan terorganisir di bawah komando 
desa adat di setiap wilayah di Bali. Hal ini bisa dilakukan karena di Bali sangat kental dengan konsep gotong royong yang dikenal dengan istilah menyama braya (bersaudara-bertetangga), konsep ini telah menjadi identitas orang Bali (Fauzi, 2019; Suarmini, 2011).

\section{Pendanaan}

Masalah selanjutnya yang muncul setelah proses pembentukan Satgas adalah sumber dana yang dipakai sebagai pendukung pelaksanaan kegiatan satgas. Jika di tingkat pemerintah nasional itu sudah jelas dipakai anggaran penanggulangan bencana yang secara pasti sudah ada. Namun di tingkat desa adat tentu berbeda, di awal kegiatan pembentukan satgas ini dikalangan masyarakat adat dipandang sebagai kegiatan sukarela (ngayah). Namun karena waktu yang tidak pasti dan juga membutuhkan sarana penunjang, maka itu menjadi persoalan yang sangat pelik. Tentu harus ada kebijakan pasti untuk mencegah munculnya permasalahan baru. Oleh karena itu Pemerintah Provinsi Bali mengeluarkan kebijakan melakukan revisi anggaran desa adat (Dhae, 2020).

Adanya kebijakan revisi anggaran desa adat di Bali, disebabkan karena desa adat ini mendapatkan bantuan dana sebesar Rp. 300.000.000,- pertahunnya dari Pemerintah Provinsi Bali. Kebijakan awalnya, masing-masing desa adat diberikan mempergunakan dana Desa adat sebanyak Rp. 50.000.000,- untuk penangganan COVID-19. Setelah dievaluasi dana dengan jumlah demikian tidak cukup kemudian dikeluarkan kebijakan baru dana Desa adat yang bisa dipakai maksimal Rp. 150.000.000,-. Persoalan pendanaan akhirnya bisa diselesaikan dengan segera, karena sejak awal dana desa adat sudah memiliki dana dan diberikan ke masing-masing rekening desa adat. Kebijakan ini tentunya sangat mempercepat penanggulangan dampak COVID-19 di daerah Bali.

\section{Kewenangan dalam melakukan tindakan yang terbatas}

Kemudian persoalan yang timbul adalah adanya keterbatasan jangkauan dari setiap desa adat dalam menyelesaikan permasalahannya yaitu di wilayah desa adatnya sendiri. Karena sejatinya setiap desa adat memiliki awig-awig (aturan) sendiri yang mengatur masyarakatnya (Umiyati, 2020). Situasi ini menyebabkan koordinasi antar satu adat dengan adat yang lainnya juga terbatas karena terjadi pembatasan sosial (social distancing). Masingmasing desa adat ada kencenderungan berjalan sendiri-sendiri. Salah satu contohnya berkaitan dengan pembatasan keluar masuk desa adat. Seperti yang dilakukan desa adat Padang Bulia, pedagang asongan dilarang berjualan di desa itu selama pandemi ini terjadi. Di sisi lain Desa adat Runuh yang ada di sebelahnya tidak memberlakukan pembatasan tersebut. Perbedaan itu bisa saja menyebabkan kesalahpahaman di masyarakat. Persoalan yang demikian diselesaikan dengan penyampaian informasi yang lebih banyak kepada masyarakat luas di masing-masing desa. Dengan cara demikian, maka tidak akan muncul konflik kepentingan ataupun kesalahpahaman.

\section{Persoalan penerapan sanksi}

Pengendalian pandemi COVID-19 berdasarkan pendekatan Desa adat, memang tidak seluruh masyarakat mau mengikuti begitu saja. Ada saja anggota masyarakat yang tidak taat dan mengabaikan berbagai himbauan dan peraturan yang diterapkan oleh pemerintah termasuk desa adat (Aryanta, 2020). Dalam situasi inilah kemudian penegakan hukum adat dan hukum nasional dijalankan. Namun situasi itu tidak mudah seperti hukum nasional yang sudah jelas dan bersifat umum. Walaupun sejatinya desa adat bisa mengatur berbagai hal yang dipandang penting dalam konteks desa adatnya (Sudantra et al., 2015). Pada aturan desa adat yang dikenal dengan awig-awig sejatinya tidak ada aturan secara eksplisit yang 
mengatur situasi pandemi seperti saat ini. Oleh karena itu harus dirumuskan aturan atau sanksi yang spesifik. Sehingga pelanggaran aturan ini dapat diselesaikan segera. Situasi ini terjadi di Desa Sawan, Kecamatan Kubutambahan, Kabupaten Buleleng yang melaksanakan kegiatan ngaben (penguburan mayat), melibatkan banyak orang dan kemudian viral di media sosial. Akibat kejadian itu salah seorang panitia pelaksana kegiatan dijadikan tersangka oleh polisi. Kejadian seperti ini sebenarnya tidak perlu terjadi jika di desa adat tersebut terdapat aturan tentang sanksi yang sudah pasti. Karena sejatinya pelaksanaan ngaben ini berkaitan dengan desa adat, namun situasinya pada saat pandemi COVID-19 menjadi ranah hukum nasional. Hal ini menimbulkan persoalan baru dan menjadi perdebatan di masyarakat.

\section{Kesimpulan}

Penanganan COVID-19 yang menjadi kasus pandemi dunia, sudah selayaknya melibatkan semua pihak termasuk di dalamnya komponen masyarakat tradisional. Bercermin pada apa yang dilakukan oleh pemerintah Provinsi Bali melalui Surat keputusan bersama nomor 472/ 1571/PPDA/DPMA dan Nomor 05/SK/MDA-ProvBali/III/2020 antara Gubernur Bali dan Majelis Desa adat provinsi Bali tertanggal 28 Maret 2020, maka bisa dilakukan sebuah tindakan yang pasti dalam mengendalikan penyebaran kasus COVID-19 di Bali. Namun demikian kesadaran masyarakat jauh lebih penting dalam rangka memotong rantai penyebaran Virus COVID-19 ini. Selain itu, kepastian hukum dan jaminan ekonomi berupa bantuan bagi masyarakat yang terkena dampak dari COVID-19 sangat dibutuhkan. Hal ini penting dilakukan agar kerja keras yang telah dilakukan oleh pemerintah dan lembaga desa adat di Bali tidak sia-sia. Di balik semua itu penanganan penyebaran COVID-19 berbasis adat dengan menerapkan kearifan lokal seperti Tri Hita Karana di Bali bisa dijadikan role model bagi pengendalian pandemi COVID-19. Hal ini penting dilakukan dalam rangka untuk menyambut new normal. Pelibatan masyarakat secara holistik akan menimbulkan kesadaran kolektif dalam mencegah penyebaran COVID-19 semakin masif.

\section{Daftar Pustaka}

Adharinalti, A. (2012). Eksistensi Hukum Adat dalam Penyelenggaraan Pemerintahan Desa di Bali. Jurnal Rechtsvinding, 1(3), 409-418.

Agung, A. A. G. (2020). Covid-19, Pemprov Bali Lakukan Pendataan Berbasis Desa adat. Diakses dari www.gatra.com.

AMN. (2020). Cara Mengajukan Permohonan Penetapan PSBB Untuk Solusi COVID-19. https://COVID-19.kemkes.go.id/warta-infem/cara-mengajukan-permohonan-penetapanpsbb-untuk-solusi-covid-19/\#.Xvla-ecxWUk

Arjawa, I. B. S., \& Jayantiari, I. M. R. (2017). Democratic Values in Balinese Traditional Society: Analysis of The Making and The Content of Desa Pakraman's Awig-Awig. Masyarakat, Kebudayaan dan Politik, 30(4), 428-436.

Arsawati, N. N. J. (2016). Pecalang Existence in Keeping Public Order and Safety of Pakraman on the Celebration of Nyepi in Bali. International Research Journal of Management, IT \& Social Sciences, 3(9), 9-18. https://doi.org/10.21744/irjmis.v3i9.167

Aryanta, I. K. A. (2020). Desa adat di Badung Setuju Keputusan MDA Bali Beri Sanksi Bagi Desa adat Tak Patuh Protokol Covid-19. Diakses dari https://bali.tribunnews.com/.

Balitribune.co.id. (2020). Presiden Puji Penanganan Covid-19 di Bali Berbasis Desa adat. Diakses dari https://bali.tribunnews.com/. 
Budiantara, I. K. D. (2017). Implementasi Ajaran Tri Hita Karana pada Masyarakat Hindu di Desa Sengkidu Kecamatan Manggis Kabupaten Karangasem. Lampuhyang: Jurnal Ilmiah Pendidikan, Agama, dan Kebudayaan, 8(2), 1-7.

Covid.go.id. (2020). Peta Sebaran. Diakses dari https://COVID-19.go.id/.

Danandjaja, J. (2014). Metode Penelitian Kepustakaan. Antropologi Indonesia, 52(1), 101 106. https://doi.org/10.7454/ai.v0i52.3318

Devita, R. (2020). Ratusan Desa adat Sudah Bentuk Satgas Covid-19. Diakses dari http://www.balipost.com/.

Dhae, A. (2020). Pemprov Bali akan Pertaruhkan APBD 2020 untuk Covid-19. Diakses dari https://mediaindonesia.com/.

Fauzi, A. F. (2019). Internalisasi Nilai-Nilai Multikultural Melalui Budaya Nyama Beraya Pada Masyarakat Muslim Pegayaman. Al-Mada: Jurnal Agama, Sosial, dan Budaya, 2(1), 1-21. https://doi.org/10.31538/almada.v2i1.220

Febriyandi, F. (2020). Penanganan Wabah Covid-19 dengan Pendekatan Budaya. Diakses dari https://kebudayaan.kemdikbud.go.id/.

Hadiwardoyo, W. (2020). Kerugian Ekonomi Nasional Akibat Pandemi Covid-19. Baskara: Journal of Business and Entrepreneurship, 2(2), 83-92. https://doi.org/10.24853/ baskara.2.2.83-92

Harahap, D. A. (2020). Corona Virus dan Panik Buying yang Impulsif. Diakses dari https://www.radarbandung.id/2020/04/06/virus-corona-dan-panic-buying-yangimpulsif/

Ibnu, Y., \& Setiawan, S. (2020). Penetapan Karantina Wilayah Menurut Pandangan Legal Positivisme Dalam Rangka Pencegahan dan Pemberantasan Pandemi Coronavirus Disease (Covid) -19. Diakses dari https://osf.io/preprints/zfg6x/

Ihsanuddin, I. (2020). Fakta Lengkap Kasus Pertama Virus Corona di Indonesia. Diakses dari www.kompas.com.

Izzaty, I. (2020). Kebijakan Pemerintah Dalam Mengatasi Panic Buying Akibat Covid-19. Diakses dari http://sdip.dpr.go.id/search/detail/category/Info\%20Singkat/id/1044

Karmini, N. W., Wiana, M. Y., \& Sukarma, I. W. (2019). Pendidikan Lingkungan Hidup Bagi Generasi Melenial Pada Era 4.0. Dharmasmrti: Jurnal Ilmu Agama dan Kebudayaan, 19(2), 11-20. https://doi.org/10.32795/ds.v19i2.419

Kemendikbud. (2020). Pencegahan Penyebaran Virus Covid-19 dengan Kerja di Rumah bagi ASN. Diakses dari menpan.go.id.

Kemenkes RI. (2020). Peraturan Menteri Kesehatan Republik Indonesia Nomor 9 Tahun 2020 Tentang Pedoman Pembatasan Sosial Berskala Besar Dalam Rangka Percepatan Penanganan Corona Virus Disease 2019 (Covid-19). Kementerian Kesehatan RI.

Ketut Arya Sunu, I. G. (2015). Harmonisasi, Integrasi Desa Pakraman dengan Desa Dinas yang Multietnik dan Multiagama Menghadapi Pergeseran, Pelestarian, dan Konflik di Bali. Jurnal Ilmu Sosial dan Humaniora, 3(2), 446-458. https://doi.org/10.23887/jishundiksha.v3i2.4469

Lestari, N. P. (2020). Menimbang Mahalnya Biaya Lockdown. Diakses dari https://www.harianbhirawa.co.id/menimbang-mahalnya-biaya-lockdown/

Mustofa, A. (2020). Putus Wabah Covid-19, Penutupan Objek Wisata di Badung Diperpanjang. Diakses di https://radarbali.jawapos.com/.

Undang-Undang Nomor 24 Tahun 2007 tentang Penanggulangan Bencana.

Pitana, I. G. (1994). Dinamika Masyarakat dan Kebudayaan Bali. Denpasar: Bali Post. 
Putra, T. C. (2020). Benteng Terakhir Bali Bernama Desa adat. Diakses di www.balipuspanews.com.

Rahmawati, P. I., Jiang, M., Law, A., Wiranatha, A. S., \& De Lacy, T. (2019). Spirituality and Corporate Social Responsibility: An Empirical Narrative From The Balinese Tourism Industry. Journal of Sustainable Tourism, 27(1), 156-172. https://doi.org/10.1080/09669582.2018.1513006

Redaksi WE Online. (2020). Jumlah Pasien Positif Corona Terus Bertambah di Bali. Diakses di www.wartaekonomi.co.id.

Setiada, K. N. (2003). Desa adat Legian ditinjau Dari Pola Desa Tradisional. Jurnal Permukiman Natah, 1(2), 52-108.

Setiada, N. K. (2003). Desa adat Legian Ditinjau Dari Pola Desa Tradisional Bali. Jurnal Natah, 1(2), 52-108. https://doi.org/https://ojs.unud.ac.id/index.php/natah/article/ download/2933/2094/

Siregar, P. P., \& Zahra, A. H. (2020). Bencana Nasional Penyebaran COVID-19 sebagai Alasan Force Majeure, Apakah Bisa? Diakses di https://www.djkn.kemenkeu.go.id/ artikel/baca/13037/Bencana-Nasional-Penyebaran-COVID-19-sebagai-Alasan-ForceMajeure-Apakah-Bisa.html.

Suarmini, N. W. (2011). Peranan "Desa Pakraman" Dalam Memperkuat Ketahanan Sosial Budaya Melalui Konsep Ajaran "Tri Hita Karana." Jurnal Sosial Humaniora, 4(1), 112. https://doi.org/http://dx.doi.org/10.12962/j24433527.v4i1.635

Sudantra, I. K. (2014). Pengaturan Peradilan Adat dalam Awig-Awig Desa Pakraman: Studi Pendahuluan Tentang Eksistensi Peradilan Adat dalam Kesatuan Masyarakat Hukum Adat Desa Pakraman. Jurnal Magister Hukum Udayana (Udayana Master Law Journal), 3(2), 44-120. https://doi.org/10.24843/jmhu.2014.v03.i02.p06

Sudiatmaka, K., \& Apsari Hadi, I. G. A. (2018). Penyuratan Awig-Awig Desa Pakraman. Jurnal Komunikasi Hukum (JKH), 4(1), 46-58. https://doi.org/10.23887/jkh.v4i1.13659

Suherni, N. (2020). Hindari Kerumunan, Ritual Melasti di Kuta Bali Hanya Libatkan 25 Orang. Diakses dari https://bali.inews.id/.

Sukarma, I. W. (2016). Tri Hita Karana: Theoretical Basic of Moral Hindu. International Journal of Linguistics, Literature and Culture, 2(3), 102-116. https://doi.org/10.21744/ ijllc.v2i3.230

Sumarjo, S. (2018). Eksistensi Awig-Awig dalam Menjaga Harmonisasi. Habitus: Jurnal Pendidikan Sosiologi, dan Antropologi, 2(1), 27-39.

Tim COVID-19 IDAI. (2020). Protokol Tatalaksana Covid-19. Diakses dari https://www.idai.or.id/about-idai/idai-statement/protokol-tatalaksana-covid-19

Umiyati, M. (2020). The Existence of Natural Lexicons in 'Awig-Awig' Tenganan Pegringsingan Bali: An Ecolinguistic Approach. Jurnal Kajian Bali (Journal of Bali Studies), 1(1), 23-27. https://doi.org/10.24843/jkb.2020.v10.i01.p09

Wikipedia. (2020). Pandemi koronavirus 2019-2020. https://id.wikipedia.org/. 